\title{
A New $\alpha_{5} \beta_{1}$ Integrin-Dependent Survival Pathway Through GSK3ß Activation in Leukemic Cells
}

\author{
Fabienne De Toni-Costes ${ }^{1,2}$, Mathieu Despeaux ${ }^{1,2}$, Jessica Bertrand ${ }^{1,2}$, Ezzeddine Bourogaa ${ }^{1,2}$, Loïc \\ Ysebaert $^{1,2,3}$, Bernard Payrastre ${ }^{1,2}$, Claire Racaud-Sultan ${ }^{1,2 *}$
}

1 Unité 563, Institut National des Sciences et de la Recherche Médicale, Toulouse, France, 2 Université Toulouse III Paul-Sabatier, Centre de Physiopathologie de Toulouse Purpan, Toulouse, France, $\mathbf{3}$ Centre Hospitalier Universitaire de Toulouse, Hôpital Purpan, Service d'Hématologie, Toulouse, France

\begin{abstract}
Background: Cell survival mediated by integrin engagement has been implicated in cell adhesion-mediated drug resistance. We have recently demonstrated that the activation of glycogen synthase kinase $3 \beta$ (GSK3 $\beta$ ) is a new pathway supporting the chemoresistance of leukemic cells adhered to fibronectin.

Methodology and Principal Findings: We show here that in conditions of serum starvation, the fibronectin receptor $\alpha_{5} \beta_{1}$ integrin, but not $\alpha_{4} \beta_{1}$, induced activation of GSK3 $\beta$ through Ser-9 dephosphorylation in adherent U937 cells. The GSK3 $\beta$ dependent survival pathway occurred in adherent leukemic cells from patients but not in the HL-60 and KG1 cell lines. In adhesion, activated GSK3 $\beta$ was found in the cytosol/plasma membrane compartment and was co-immunoprecipitated with $\alpha_{5}$ integrin, the phosphatase PP2A and the scaffolding protein RACK1. PP2A and its regulatory subunit B' regulated the Ser-9 phosphorylation of GSK3 $\beta$. In adherent leukemic cells, $\alpha_{5} \beta_{1}$ integrin but not $\alpha_{4} \beta_{1}$ upregulated the resistance to TNF $\alpha$ induced apoptosis. Both extrinsic and intrinsic apoptotic pathways were under the control of $\alpha_{5} \beta_{1}$ and GSK3 $\beta$.
\end{abstract}

Conclusions and Significance: Our data show that, upon serum starvation, $\alpha_{5} \beta_{1}$ integrin engagement could regulate specific pro-survival functions through the activation of GSK3 $\beta$.

Citation: De Toni-Costes F, Despeaux M, Bertrand J, Bourogaa E, Ysebaert L, et al. (2010) A New $\alpha_{5} \beta_{1}$ Integrin-Dependent Survival Pathway Through GSK3 $\beta$ Activation in Leukemic Cells. PLoS ONE 5(3): e9807. doi:10.1371/journal.pone.0009807

Editor: Gordon Langsley, INSERM U567, Institut Cochin, France

Received November 21, 2009; Accepted March 3, 2010; Published March 23, 2010

Copyright: (C) 2010 De Toni-Costes et al. This is an open-access article distributed under the terms of the Creative Commons Attribution License, which permits unrestricted use, distribution, and reproduction in any medium, provided the original author and source are credited.

Funding: Financial support was obtained from the Association de Recherche contre le Cancer ( $\mathrm{N}^{\circ} 3638, \mathrm{~N}^{\circ} 8407$ ), the Institut National du Cancer (N ${ }^{\circ} 07 / 3 \mathrm{D} 1616 /$ IABC-23-8/NC-NG), the Conseil Régional de Midi-Pyrénées and the DGRSRT/INSERM Franco-Tunisian cooperation. The funders had no role in study design, data collection and analysis, decision to publish, or preparation of the manuscript.

Competing Interests: The authors have declared that no competing interests exist.

* E-mail: claire.racaud@inserm.fr

\section{Introduction}

The glycogen synthase kinase $3 \beta$ (GSK $3 \beta$ ) is a serine/threonine protein kinase that is involved in many physiological processes, playing important roles in glucose metabolism, cell cycle division, cell adhesion and apoptosis. Deregulation of GSK $3 \beta$ activity is implicated in the pathogenesis of neurodegenerative and metabolic disorders, but also in cancer [1]. GSK $3 \beta$ is constitutively active under its Tyr-216 phosphorylated form and regulates many intracellular signaling pathways. At the post-translational level, the function of GSK $3 \beta$ is inhibited through phosphorylation of the Ser 9 residue by other protein kinases, including Akt, in response to insulin and growth factors [2].

Following integrin engagement, both inhibition and activation of GSK $3 \beta$ have been described. GSK-3 $\beta$ is inhibited by Ser- 9 phosphorylation by the ILK/Akt and Cdc42/PKC' pathways to promote integrin-mediated cell proliferation or migration, respectively $[3,4]$. Conversely, cell adhesion to a $3 \mathrm{D}$ collagen matrix through $\alpha_{2} \beta_{1}$ engagement promotes activation of GSK3 $\beta$ as well as protein phosphatase 2A (PP2A) [5]. PP2A has been previously shown to reactivate GSK3 $\beta$ through dephosphorylation of Ser-9 $[6,7]$. However, no role has been ascribed to the activated form of GSK $3 \beta$ downstream of integrin engagement.
We have previously shown that GSK $3 \beta$ activation promotes the chemoresistance of adherent leukemic cells on fibronectin or on osteoblasts under serum starvation [8]. The endosteal niche supports chemoresistant leukemic stem cells [9] and is thought to be rich in fibronectin and hypoxic [10]. Adhesion of serum-starved leukemic cells to fibronectin through $\alpha_{4} \beta_{1}$ and $\alpha_{5} \beta_{1}$ engagement allows both Ser-9 dephosphorylation of GSK $3 \beta$ and NF- $\kappa$ B activation [8]. Others and we have demonstrated that GSK $3 \beta$ can upregulate cell survival through epigenetic and IkB-independent control of NF- $\kappa \mathrm{B}$ activity $[8,11-14]$. Strikingly, the anti-apoptotic role of GSK $3 \beta$ has been demonstrated in different tumors and may involve resistance to death receptor-induced apoptosis [1520]. Recently, GSK $3 \beta$ was found associated with DDX3 and cIAP-1 in a death antagonizing signaling complex at death receptors and the resistance to apoptosis was overcome by GSK3 inhibitors [21]. A mitochondrial-mediated cell death was also found regulated by GSK3 [22].

Adhesion to fibronectin through $\alpha_{4} \beta_{1}$ and $\alpha_{5} \beta_{1}$ engagement supports cell adhesion-mediated drug resistance (CAM-DR) of many tumors [23]. Different specific fibronectin domains are bound by $\alpha_{4} \beta_{1}$ and $\alpha_{5} \beta_{1}$ integrins and could each induce opposing effects on cell survival and proliferation [24]. The aim of our study was thus to determine the respective roles of $\alpha_{4} \beta_{1}$ and $\alpha_{5} \beta_{1}$ in 
GSK $3 \beta$ activation in serum-starved adherent leukemic cells. Our results demonstrate that $\alpha_{5} \beta_{1}$ but not $\alpha_{4} \beta_{1}$ regulates a signaling pathway leading to GSK $3 \beta$ activation and cell survival.

\section{Materials and Methods}

\section{Antibodies and pharmacological inhibitors}

Monoclonal antibodies against GSK3 $\beta$, flotillin and RACK1 were from BD Transduction Laboratories. Monoclonal antibodies GSK $3 \alpha / \beta$, actin and integrin subunits $\left(\alpha_{5}\right.$, P1D6; $\alpha_{4}$, P4G9) were purchased from Upstate or Biosource International (Camarillo, CA, USA), Sigma and Dako (Carpinteria, CA, USA), respectively. Monoclonal antibodies against $\alpha_{5}$ subunit (clone JBS5), Akt and caspases were from Chemicon International, Santa Cruz Biotechnology (Santa Cruz, CA, USA) and Cell Signaling technology (Beverly, MA, USA), respectively. Polyclonal antibodies directed against PP2A-A (catalytic subunit of PP2A) and PP2A tyrosine phosphorylated at position 307 were from Santa Cruz Biotechnology, and those against integrin subunits $\left(\alpha_{4}\right.$ and $\left.\alpha_{5}\right)$ came from Chemicon International. Polyclonal antibodies directed against PP2A-B' (regulatory subunit of PP2A), cytochrome C, GSK3 $\alpha$ / $\beta$ serine phosphorylated at position $21 / 9$ and Akt threonine phosphorylated at position 308 were from Cell Signaling Technology. Polyclonal antibody against p85 was from Upstate. Horseradish-peroxydase-conjugated secondary antibodies against mouse, rabbit or goat were from Cell Signalling Technology. Okadaic acid, a PP2A inhibitor, and the GSK3 $\beta$ inhibitor SB216763 were from Sigma. For Western blotting after immunoprecipitation, GSK3 $\beta$ (monoclonal from BD Transduction Laboratories) and P(ser9)GSK3 $\beta$ (polyclonal from Abcam) antibodies have been biotynylated in our laboratory.

\section{Cells and cell culture}

The human leukemic cell lines U937, HL-60 and KG1 were purchased from the German Collection of Microorganisms and Cell Cultures (Braunschweig, Germany). U937 and HL-60 cells were grown at $37^{\circ} \mathrm{C}$ in $5 \% \mathrm{CO}_{2}$ in RPMI-1640, containing $10 \%$ FCS, $50 \mu \mathrm{g} / \mathrm{ml}$ penicillin, and $50 \mu \mathrm{g} / \mathrm{ml}$ streptomycin. KG1 cells were grown in the same conditions in IMDM 20\% FCS. Bone marrow leukemic cells from patients with acute myeloid leukemia (AML) were obtained upon informed consent and processed for their conservation as described previously [8]. Leukemic samples were characterized at the Hematology Department of Toulouse University Hospital (France), classified along French American British (FAB) classification (FAB0: undifferentiated AML; FAB1: myeloblastic AML; FAB2: myeloblastic with differentiation AML; FAB4: myelomonocytic AML; FAB5: monocytic AML). The samples contained more than $80 \%$ leukemic blasts after processing. After thawing, viable cells from patients were checked by blue trypan labelling, resuspended in IMDM, then washed once and quickly used for in vitro experiments.

\section{Transfection of siRNA}

U937 cells were transfected using the Amaxa nucleofection technology (Amaxa, Koeln, Germany), as indicated in [8]. $6 \times 10^{6}$ $\mathrm{U} 937$ cells in $100 \mu \mathrm{l}$ solution $\mathrm{V}$ were mixed with $200 \mathrm{nM}$ siRNA GSK3 $\beta, 100 \mathrm{nM}$ siRNA PP2A-B' or with 100-200 nM nontargeting siRNA (Dharmacon Inc., Lafayette, CO, USA). For siRNA integrin, two sources have been used to target $\alpha_{4}$ and $\alpha_{5}$ subunits: Ambion $(30 \mathrm{nM})$ and Qiagen $(50 \mathrm{nM})$. Cells were immediately nucleofected with an Amaxa Nucleofector apparatus (Amaxa, program V01), then transferred into wells containing $37^{\circ} \mathrm{C}$ prewarmed culture medium in six-well plates. After transfection, cells were cultured from 24 to $96 \mathrm{~h}$ before analysing by Western blotting or FACS. Decrease of GSK $3 \beta$ and $\alpha_{4}$ integrin subunit was maximal at $48 \mathrm{~h}$ and maintained at $72 \mathrm{~h}$ whereas decrease of PP2A-B' and $\alpha_{5}$ integrin subunit was maximal at $72 \mathrm{~h}$. Therefore, survival tests and Western blot analysis were performed at $72 \mathrm{~h}$ post-nucleofection.

\section{Western blotting}

For Western blotting, $0.5-1 \times 10^{6}$ cells washed in Phosphate Buffer Saline (PBS) were denatured in Laemmli sample buffer. After sonication for 10 seconds and boiling for $10 \mathrm{~min}$, proteins were resolved on polyacrylamide SDS gels (SDS-PAGE) and transferred to nitrocellulose (membrane Hybond-G super, Millipore). The membrane was blocked for $1 \mathrm{~h}$ at room temperature in Tris-buffered saline (TBS) containing 5\% fat-free milk and then was probed overnight at $4{ }^{\circ} \mathrm{C}$ with the appropriate monoclonal or polyclonal antibodies in TBS, $0.1 \%$ Tween, $3 \%$ fat-free milk and 3\% Bovine Serum Albumin (BSA, Euromedex). After incubation for $1 \mathrm{~h}$ at room temperature with either anti-mouse or anti-rabbit IgG antibody coupled to horseradish peroxidase, or streptavidinHRP, detection was achieved using a chemiluminescent substrate (SuperSignal, Amersham Pharmacia Biotech).

\section{Survival and adhesion assays}

We have previously set-up a protocol to study the survival pathway in leukemic cells strictly dependent on the integrin engagement without extrinsic growth factors that should not be found in the leukemic niche [8]. Thus, adhesion assays and treatments of cells were performed during $5 \mathrm{~h}$ of serum starvation followed by re-addition of serum to discard serum deprivationlinked cytotoxicity, and cell viability was measured at $24 \mathrm{~h}$. Since adhesion under serum-starved conditions was required to trigger GSK $3 \beta$ activation downstream of integrin engagement (preliminary experiments not shown), we have thus measured the differential of GSK3 $\beta$-linked cell survival between suspension and adhesion upon serum-starved conditions. Half of a 96 well microtiter plate (MaxiSorp Immuno Plate, Nunc, Denmark) was coated overnight at $4^{\circ} \mathrm{C}$ with $40 \mu \mathrm{g} / \mathrm{ml}$ of human fibronectin (Roche Molecular Biochemicals, Mannheim, Germany) in a final volume of $50 \mu \mathrm{l}$ in PBS, and subsequently incubated with $1 \%$ fatty acid-free BSA in PBS to block non specific adhesion sites, $1 \mathrm{~h}$ at room temperature. Leukemic cells were diluted to $0.3 \times 10^{6} / \mathrm{ml}$, left overnight (cell lines) or immediately processed after thawing (AML cells, protocol described below) and then serum-starved for $1 \mathrm{~h}$, incubated or not with okadaic acid $(100 \mathrm{nM})$ or SB216763 $(10 \mu \mathrm{M})$. Then, cells were allowed to adhere on fibronectin-coated microtiter 96 well plates $\left(0.8 \times 10^{5}\right.$ cells/well $)$ for $1 \mathrm{~h}$ at $37^{\circ} \mathrm{C}$ or maintained in suspension. Where shown, leukemic cells in suspension or adhesion were treated with $10 \mathrm{ng} / \mathrm{ml} \mathrm{TNF} \alpha$ for 4 hours after which cells were washed and incubated in serumcontaining medium for $24 \mathrm{~h}$ at $37^{\circ} \mathrm{C}$. Cell viability was then quantified by methyl thiazolyl tetrazolium (MTT) assay (Sigma). In some experiments, leukemic cells were allowed to adhere on a surface coated with $\alpha_{4^{-}}$or $\alpha_{5}$-specific antibodies (clones P4G9, P1D6, JBS5: $1,0.1 \mu \mathrm{g} / \mathrm{ml}$ and $0.2 \mu \mathrm{g} / \mathrm{ml}$ for optimal adhesion, respectively) as previously described in [8]. Assays were performed in triplicate. For the quantification of cell adhesion, adherent cells were washed in PBS, fixed with a Karnovsky solution and stained with $0.1 \%$ crystal violet solution.

For the apoptosis assay, $1 \times 10^{6} \mathrm{U} 937$ cells treated with control, GSK $3 \beta$ or integrin siRNAs were processed as described for the survival assay and at $5 \mathrm{~h}$ of incubation were washed with $1 \mathrm{x}$ PBS and then incubated $15 \mathrm{~min}$ at room temperature with a FITClabeled Annexin-V/propidium iodide solution (Sigma). These cells were directly analysed in a FACScan (Becton Dickinson) with a 
A

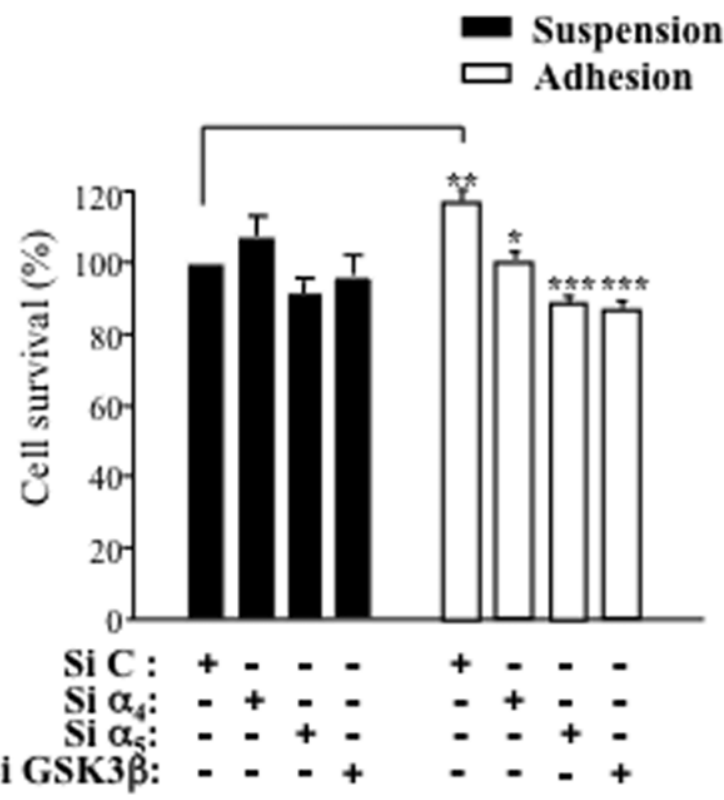

B
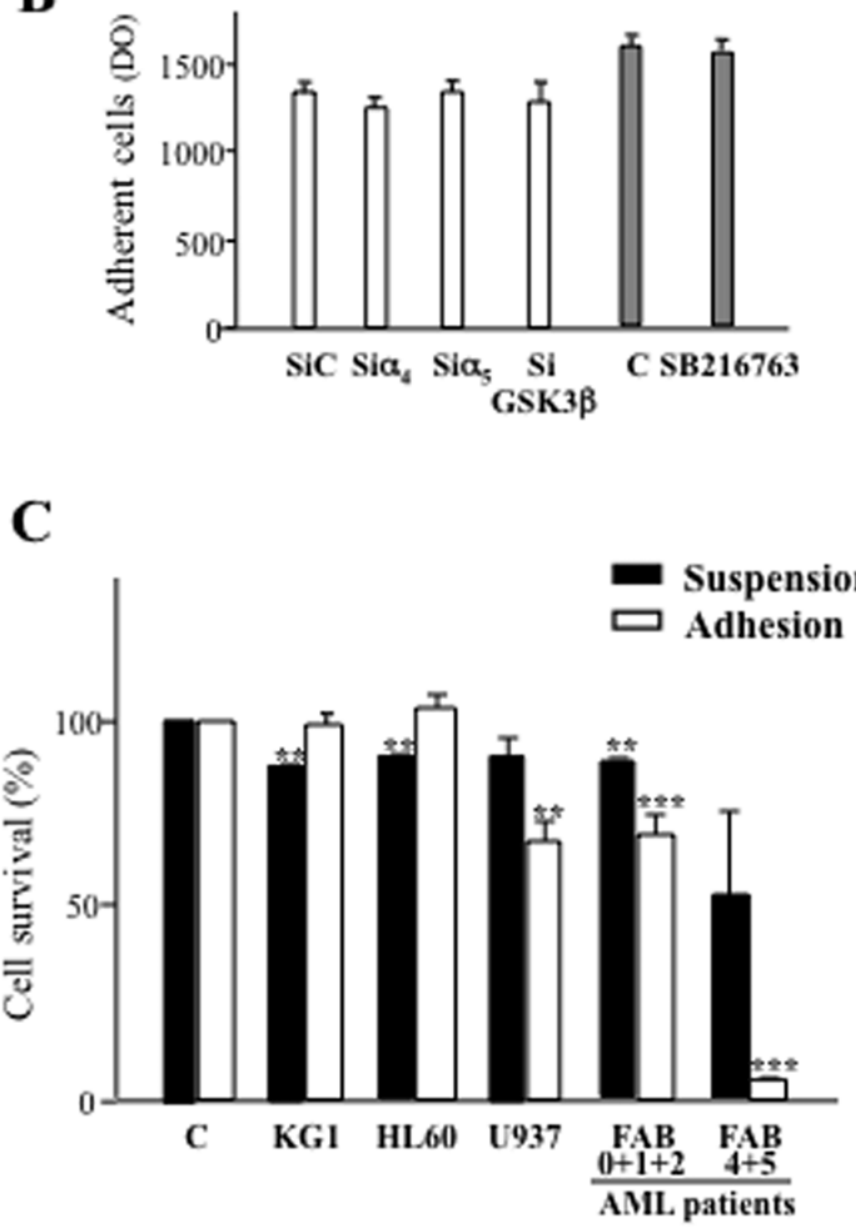

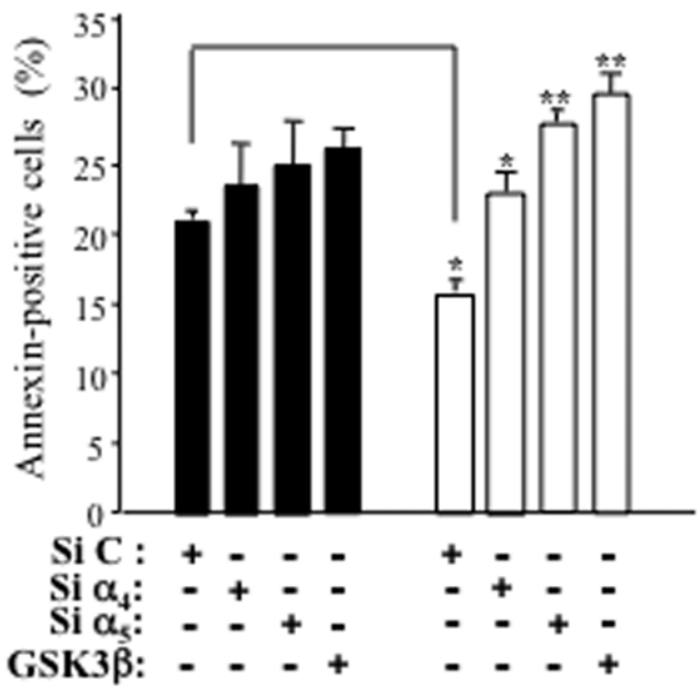

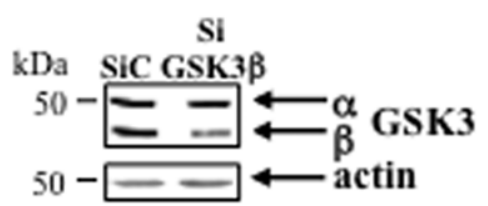

D Susp. Adh.
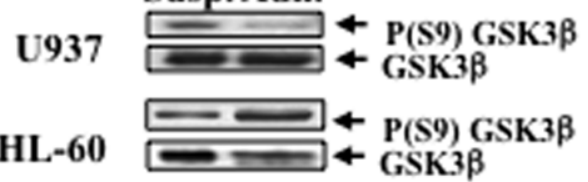

KG1

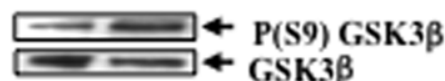

AML patient

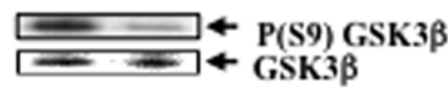

Figure 1. Implication of GSK3 $\beta, \alpha_{4} \beta_{1}$ and $\alpha_{5} \beta_{1}$ integrins in the survival of adherent leukemic cells. A- 72 hours after nucleofection of siRNA directed to GSK3 $\beta, \alpha_{4}$ or $\alpha_{5}$ subunits, U937 were serum starved, adhered to fibronectin, and then underwent a survival assay 24 hours later with MTT (left panel, $n=6$, mean \pm S.E.M.) or 5 hours later with annexin-PI labeling (right panel, $n=4$, mean \pm S.E.M.). In MTT assays, data are expressed as 
percentage of survival compared to the non-targeting siRNA ( $\mathrm{SiC}$ ) in suspension. Statistical analysis on compared adhesion/suspension controls and SiC/SiGSK3 or SiC/Silntegrin in adhesion: ${ }^{*} P<0.05,{ }^{* * P}<0.01,{ }^{* * * P}<0.001$. B- The adhesive capacity of siRNA- or SB216763-treated U937 was measured by colorimetry (left panel, $n=3$, mean \pm S.E.M.). SiRNA efficacy against GSK3 $\beta, \alpha_{4} \beta_{1}$ and $\alpha_{5} \beta_{1}$ was checked by Western blot (right panel, representative of three independent experiments). C- Survival assay (MTT) was performed as described in Material and Methods with the leukemic cell lines U937, HL-60, KG1 ( $n=3$, mean \pm S.E.M.) and the leukemic cells from patients $(n=8$, mean \pm S. E. M.: 1 FAB0, 3 FAB1, 1 FAB2, 1 FAB4, 2 FAB5) after treatment with the GSK3 $\beta$ inhibitor, SB216763 $(10 \mu \mathrm{M})$. Variations of cell survival in cells treated by SB216763 compared to the untreated cells in suspension or in adhesion are shown: ${ }^{* *} P<0.01,{ }^{* * *} P<0.001$. D- Variations of the Ser-9 phosphorylation of GSK3 $\beta$ upon adhesion on fibronectin of U937, HL-60, KG1 and AML patient cells (FAB 5) are shown. Representative of three independent experiments. doi:10.1371/journal.pone.0009807.g001

sample size of at least 10,000 cells gated on the basis of forward and side scatter. Storing and processing of data was accomplished using FACScan software and allowed the determination of the percentages of living, apoptotic and necrotic cells. Following the protocol described above including adhesion and TNF treatment upon serum starvation, the apoptotic effectors (caspases, cytochrome $\mathrm{C}$ ) were detected by Western blot at $4 \mathrm{~h}$ after re-addition of serum.

In our experiments, we have only used samples from AML patients that did not display cell death after thawing over $10 \%$ as checked by blue trypan labeling. After thawing, cells were cultured in IMDM without serum for $2 \mathrm{~h}$ and then allowed to adhere on fibronectin. At the end of $4 \mathrm{~h}$ adhesion, culture medium was supplemented by SVF to maintain the cells until $24 \mathrm{~h}$. Cell survival of AML blasts from patients was measured at $24 \mathrm{~h}$ by MTT labeling. Measurement of apoptosis in AML blasts treated or not by $\mathrm{TNF} \alpha$ was realized by FACS using labeling by APO2.7 (APO2.7-PC5 monoclonal antibody from Immunotech, Marseille, France), a mitochondrial membrane protein expressed during the early stages of apoptosis in relation to the release of cytochrome $\mathrm{C}$ outside the mitochondria. APO2.7 labeling has been chosen since in our control apoptotic assays performed with daunorubicin we detected interference with the Annexin- $\mathrm{V}$ fluorescence (not shown). In our experimental conditions, spontaneous death after thawing was maximally $20 \%$ at $24 \mathrm{~h}$ (not shown).

\section{Subcellular fractionation and $\alpha_{5}$ immunoprecipitation}

Culture dishes were coated overnight at $4^{\circ} \mathrm{C}$ with $40 \mu \mathrm{g} / \mathrm{ml}$ of human fibronectin in a final volume of $10 \mathrm{ml}$ in PBS and subsequently blocked with $1 \%$ fatty acid-free BSA in PBS, $1 \mathrm{~h}$ at room temperature. $30 \times 10^{6}$ cells were serum starved for $1 \mathrm{~h}$ at $37^{\circ} \mathrm{C}$, then allowed to adhere to fibronectin-coated dishes for $1 \mathrm{~h}$ at $37^{\circ} \mathrm{C}$, or maintained in suspension.

For subcellular fractionation, after washing, cells were pelleted by centrifugation $(5 \mathrm{~min}, 100 \mathrm{~g}$ ) and resuspended in a hypotonic buffer [10 mM HEPES (pH 7.2), $10 \mathrm{mM} \mathrm{KCl,} 1.5 \mathrm{mM} \mathrm{MgCl}$, $0.1 \mathrm{mM}$ EGTA, $20 \mathrm{mM} \mathrm{NaF}, 100 \mu \mathrm{M} \mathrm{Na} \mathrm{VO}_{4}, 10 \mu \mathrm{g} / \mathrm{ml}$ aprotinin, $10 \mu \mathrm{g} / \mathrm{ml}$ leupeptin and $1 \mathrm{mM}$ PMSF (Phenylmethanesulfonyl fluoride)] for 30 minutes at $4^{\circ} \mathrm{C}$, with shaking. Cells were broken up using a Dounce homogenizer (90 strokes), after which the nuclei were pelleted by centrifugation $(10 \mathrm{~min}, 1100 \mathrm{~g}$, $4^{\circ} \mathrm{C}$ ). The nuclei-free supernatant was subjected to a second $13500 \mathrm{~g}$ centrifugation for $45 \mathrm{~min}$ at $4^{\circ} \mathrm{C}$ to separate the membranes from the cytosolic fractions. The membrane pellets were resuspended in lysis buffer $[10 \mathrm{nM}$ Tris- $\mathrm{HCl}(\mathrm{pH} 7.5)$, $150 \mathrm{mM} \mathrm{NaCl}, 5 \mathrm{mM}$ EDTA, and $1 \%$ Triton X-100] and sonicated 1 minute. $50 \mu \mathrm{g}$ of total cytosolic and membrane pellet proteins were analysed by Western blotting.

For immunoprecipitation of $\alpha_{5}$ integrin, at the end of adhesion, cells were washed in PBS and lysed in a buffer containing $20 \mathrm{mM}$ Tris $\mathrm{HCl} \mathrm{pH}$ 8, $130 \mathrm{mM} \mathrm{NaCl}, 1 \%$ Triton X-100, 10\% glycerol, orthovanadate and protease inhibitors. After sonication and centrifugation at $13500 \mathrm{~g}$, supernatant was processed for protein quantification, preclearing and incubation overnight with $20 \mu \mathrm{L}$ $\alpha_{5}$ polyclonal antibodies. Then, immunoprecipitates were recovered with protein A sepharose, washed and analysed by Western blotting.

\section{Statistical analysis}

Student's t test was used for statistical analysis of $n$ independent experiments realized in vitro.

\section{Results}

\section{GSK3 $\beta, \alpha_{4} \beta_{1}$ and $\alpha_{5} \beta_{1}$ integrins are implicated in cell} survival of serum-starved adherent leukemic cells

We have previously demonstrated that $\alpha_{4} \beta_{1}$ and $\alpha_{5} \beta_{1}$ integrins, and the kinase GSK3$\beta$, regulate the chemosensitivity of adherent leukemic cells onto fibronectin [8]. Using a siRNA approach, we show that survival of adherent U937 on fibronectin in serumstarved conditions involves both GSK $3 \beta$ and $\beta_{1}$ integrins $\left(\alpha_{4} \beta_{1}\right.$ and $\alpha_{5} \beta_{1}$ ) (Fig. 1A). Decreased expression of GSK3 $\beta$ (70 $\left.\pm 10 \%\right)$, of $\alpha_{5} \beta_{1}(33 \pm 10 \%)$ and of $\alpha_{4} \beta_{1}(47 \pm 5 \%)$ was assessed by Western blotting (Fig. 1B). None of these siRNA altered the adhesive capacities of leukemic cells (Fig. 1B). Viable cell recovery 24 hours after adhesion assay on fibronectin measured by MTT labeling was increased in adhesion conditions compared to suspension (Fig. 1A, 18 $\pm 6 \%, \mathrm{p}<0.01$ ). GSK $3 \beta$ and $\alpha_{5} \beta_{1}$ siRNA induced a $30 \pm 5 \%$ decrease of cell recovery in adhesion $(\mathrm{p}<0.001)$, whereas $\alpha_{4} \beta_{1}$ siRNA was less potent $(18 \pm 5 \%, \mathrm{p}<0.05)$. No significant changes occurred in suspension upon treatment with the different siRNAs. Of note, identical results were obtained with two sources of siRNA targeting different sequences of $\alpha_{4}$ and $\alpha_{5}$ integrin genes (not shown).

Since MTT measurement could be the result of both cell survival and proliferation, apoptotic cell death was assessed after adhesion assay by annexin labeling (Fig. 1A). Whereas MTT measurement at 24 hours may reflect both apoptotic and necrotic processes, annexin labeling was realized at 5 hours to check specifically for the occurrence of apoptosis. A higher level of apoptosis was detected in U937 electroporated with control siRNA comparatively to untreated cells $(20 \pm 2 \%$ versus $\leq 10 \%)$. Adhesion decreased the amount of annexin-positive cells compared to suspension $(24 \pm 4 \%, \mathrm{p}<0.05)$. Downregulation of $\alpha_{5} \beta_{1}$ or $\alpha_{4} \beta_{1}$ expression in adherent U937 induced an increase of apoptotic cells compared to control siRNA in adhesion $(69 \pm 5 \% \quad \mathrm{p}<0.01$ and $44 \pm 6 \% \mathrm{p}<0.05$, respectively). Knockdown of GSK $3 \beta$ expression increased apoptosis of adherent U937 (81 $44 \%, \mathrm{p}<0.01)$. Apoptosis in suspension was not significantly changed after treatment with integrin siRNAs.

Using the pharmacological GSK3 $\beta$ inhibitor SB216763 at a concentration $(10 \mu \mathrm{M})$ without deleterious quantitative effect on cell adhesion (Fig. 1B), we have further demonstrated that, as well as in U937, the GSK3 $\beta$-dependent survival pathway occurred in adherent leukemic cells from patients but not in the HL-60 and KG1 leukemic cell lines (Fig. 1C). Accordingly, the activated form of GSK3 $\beta$ (dephosphorylated Ser-9 GSK3 $\beta$ ) was increased in adherent U937 and cells from AML patients, but not in adherent 
HL-60 and KG1 cells (Fig. 1D). Importantly, GSK3 $\beta$-dependent cell survival was found in adherent AML cells classified along different FAB. However the pro-apoptotic response to SB216763 occurred in 50\% AML samples of the cohort $(n=16: 3$ FAB0, 4 FAB1, 2 FAB2, 3 FAB4 and 4 FAB5) and was more pronounced in AML from myelomonocytic FAB (Fig. 1C). Furthermore, most of the blasts underwent CAM-DR in vitro and SB216763 abolished it, as previously described [8].

Altogether, these results demonstrate that engagement of $\alpha_{4} \beta_{1}$ and $\alpha_{5} \beta_{1}$ integrins to fibronectin supports cell survival of serum- starved adherent leukemic cells, potentially through activation of GSK $3 \beta$ via its dephosphorylation.

The inhibitory Ser-9 phosphorylation of GSK3 $\beta$ is differentially regulated by $\alpha_{4} \beta_{1}$ and $\alpha_{5} \beta_{1}$ integrins

To further demonstrate that GSK3 $\beta$ is involved in $\alpha_{4} \beta_{1}$ and $\alpha_{5} \beta_{1}$-mediated prosurvival effect, we used siRNA to knockdown integrin expression (Fig. 2A). We have studied consequences of the decrease in expression of each integrin on GSK3 $\beta$ phosphoryla-
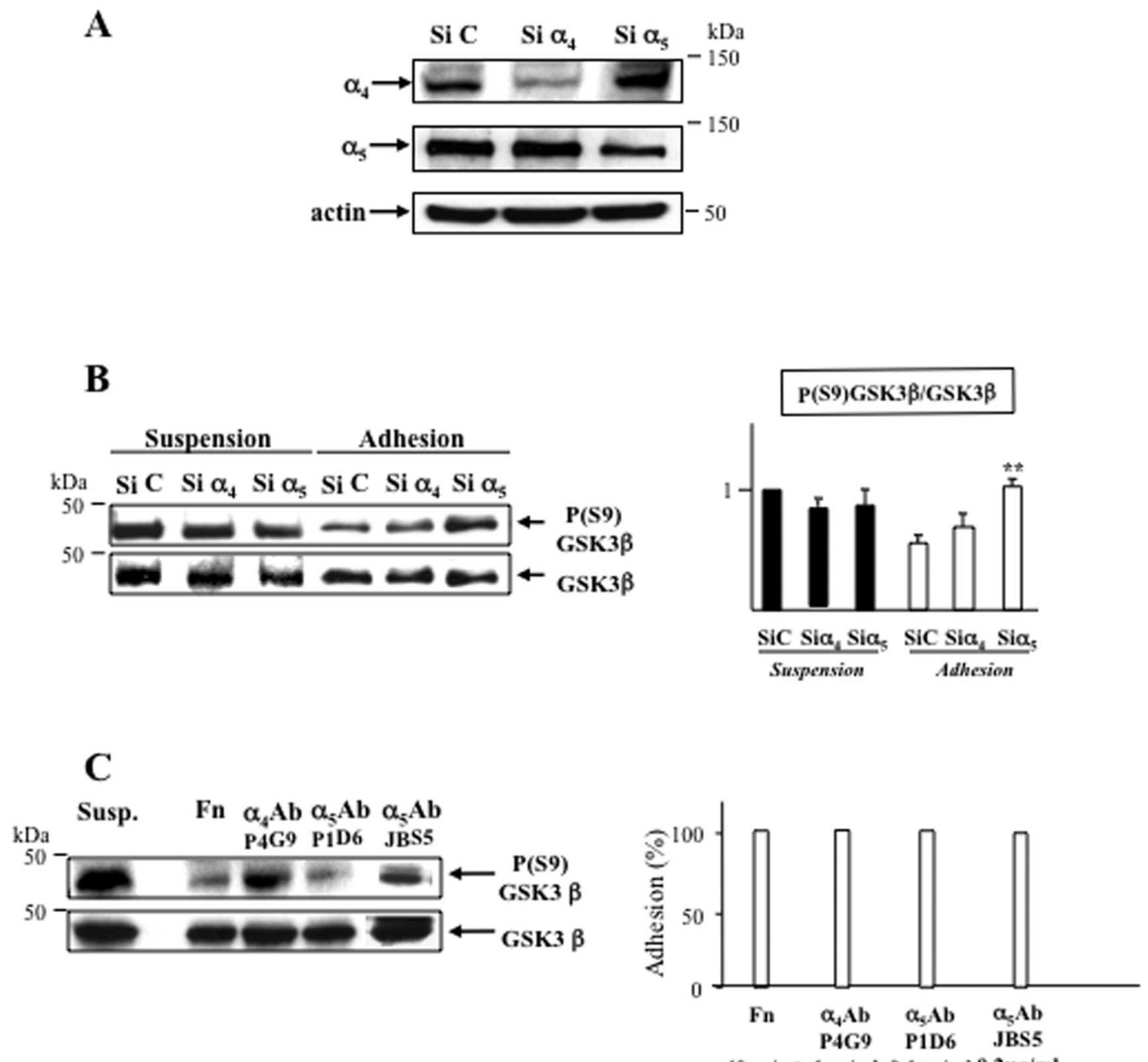

Figure 2. GSK3 $\beta$ is differentially regulated by $\alpha_{4} \beta_{1}$ and $\alpha_{5} \beta_{1}$ integrins in leukemic cells. A- Specificity and efficacy of siRNA integrins were checked by Western blot. B- Serum-starved U937 were allowed to adhere on fibronectin for $1 \mathrm{~h}$ and the Ser-9 phosphorylation state of GSK3 $\beta$ was compared to cells in suspension after downregulation of $\alpha_{4}$ and $\alpha_{5}$ expression by siRNA. SiC $=$ non-targeting siRNA. Right panel shows the mean \pm S.E.M. variations of the P(S9)GSK3 $\beta / G S K 3 \beta$ ratio analyzed by densitometry from three independent experiments. C- The phosphorylation state of GSK3 $\beta$ was studied in suspension or after adhesion of U937 on surfaces coated with fibronectin $(F n, 40 \mu \mathrm{g} / \mathrm{ml})$, anti- $\alpha_{4}(1 \mu \mathrm{g} / \mathrm{ml})$ or $-\alpha_{5}(\mathrm{clone}$ P1D6 $0.1 \mu \mathrm{g} / \mathrm{ml}$; clone JBS5 $0.2 \mu \mathrm{g} / \mathrm{ml}$ ) antibodies in experimental conditions as for B. Adhesive capacities of U937 in each condition of coating were measured by colorimetry and are shown on right panel. Data are representative of three independent experiments.

doi:10.1371/journal.pone.0009807.g002 
tion. In serum-starved conditions, $\alpha_{4}$ and $\alpha_{5}$ siRNA had different effects on the inhibitory Ser-9 phosphorylation of GSK3 $\beta$ (Fig. 2B). Ser-9 phosphorylation of GSK $3 \beta$ was decreased $(50 \% \pm 17$, $\mathrm{p}<0.05)$ upon adhesion to fibronectin compared to suspension cells. Whereas $\alpha_{5}$ siRNA abolished the Ser-9 dephosphorylation of GSK $3 \beta$ in adhered cells, $\alpha_{4}$ siRNA had no significant effect on Ser-9 phosphorylation. Conversely, in suspension, none of integrin siRNA modified significantly Ser-9 phosphorylation of GSK3 $\beta$. These results are in favor of GSK $3 \beta$ activation through Ser-9 dephosphorylation after $\alpha_{5} \beta_{1}$ engagement onto fibronectin.
Since we have previously shown that adhesion to surfaces coated with anti- $\alpha_{4}$ (clone P4G9) or $-\alpha_{5}$ (clone P1D6) stimulatory antibodies supported the chemoresistance of U937 cells [8], we studied GSK3 $\beta$ phosphorylation in U937 adhered (with the same efficiency) either to fibronectin or to $\alpha_{4}$ or $\alpha_{5}$ antibodies (Fig. 2C). Adhesion of U937 to coated anti- $\alpha_{5}$ antibodies induced a decrease of Ser-9 phosphorylation of GSK3 $\beta$ compared to suspended cells $(60 \% \pm 10, \mathrm{p}<0.01)$, thus mimicking the observations after adhesion of leukemic cells on fibronectin. However, specific engagement of $\alpha_{4} \beta_{1}$ onto coated anti- $\alpha_{4}$ antibodies did not

A

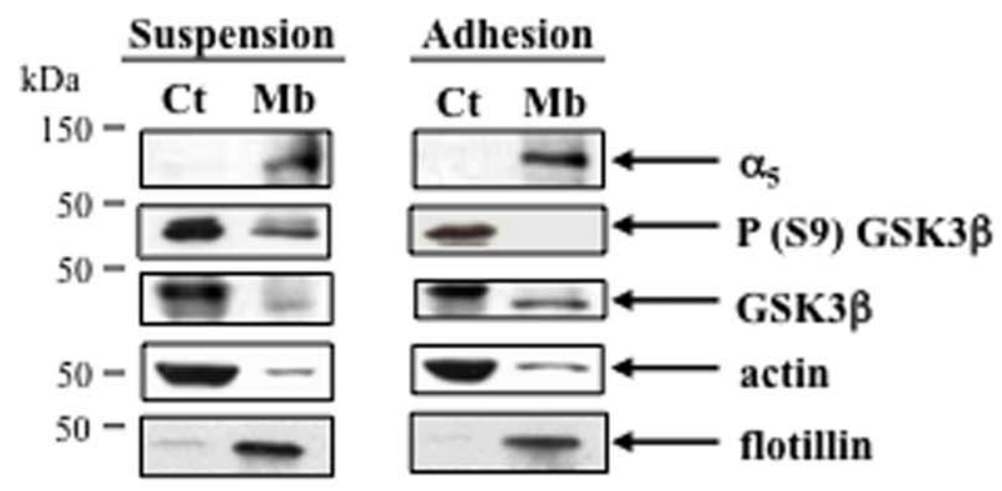

B
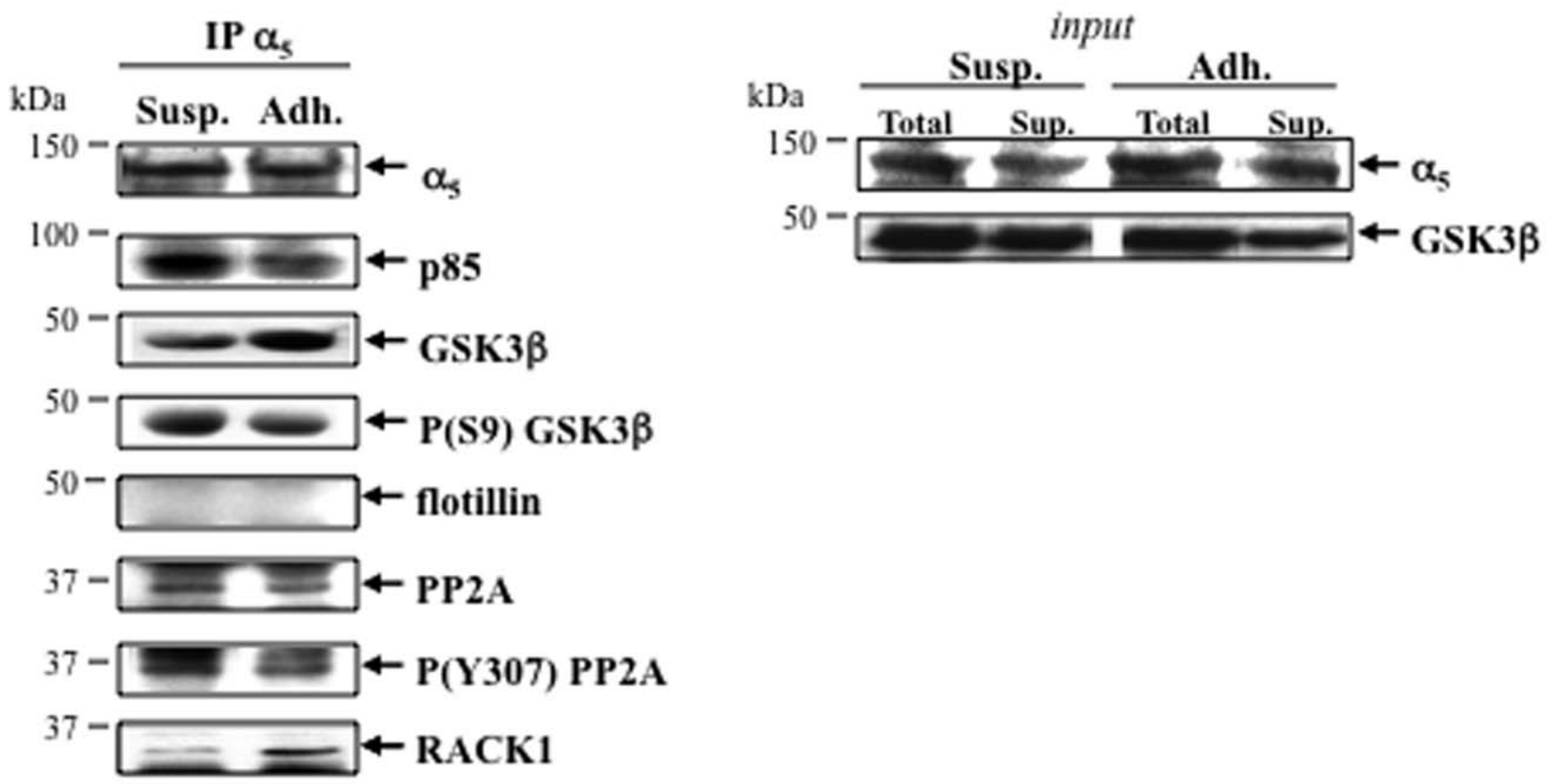

Figure 3. $\alpha_{5}$ integrin, PP2A and GSK3 $\beta$ are co-localized in adherent leukemic cells. A- The Ser-9 phosphorylation of GSK3 $\beta$ was studied by Western blot in cytosolic $(\mathrm{Ct})$ and membrane $(\mathrm{Mb})$ compartments of U937 in adhesion or in suspension. B- The presence of GSK3 $\beta$ (and its Ser-9 phosphorylated form), PP2A (and its Tyr-307 phosphorylated form), the scaffolding protein RACK1 and the PI 3-kinase regulatory subunit p85 was checked by Western blot in $\alpha_{5}$ immunoprecipitates from U937 in suspension (Susp.) or in adhesion (Adh.). The absence of flotillin in $\alpha_{5}$ immunoprecipitate demonstrates specificity of the interactions between $\alpha_{5}$ integrin, PP2A and GSK3 $\beta$. Right panel (input) indicates the amounts of $\alpha_{5}$ subunit and GSK3 $\beta$ proteins in the total lysates (Total) and in the supernatants (Sup.), before and after immunoprecipitation of $\alpha_{5}$ respectively. Data are representative of three independent experiments.

doi:10.1371/journal.pone.0009807.g003 
A

Adh.

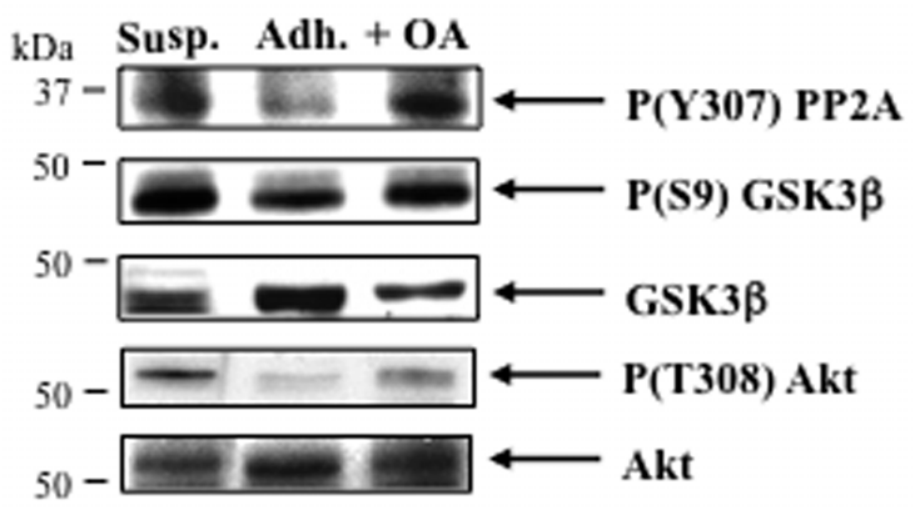

B

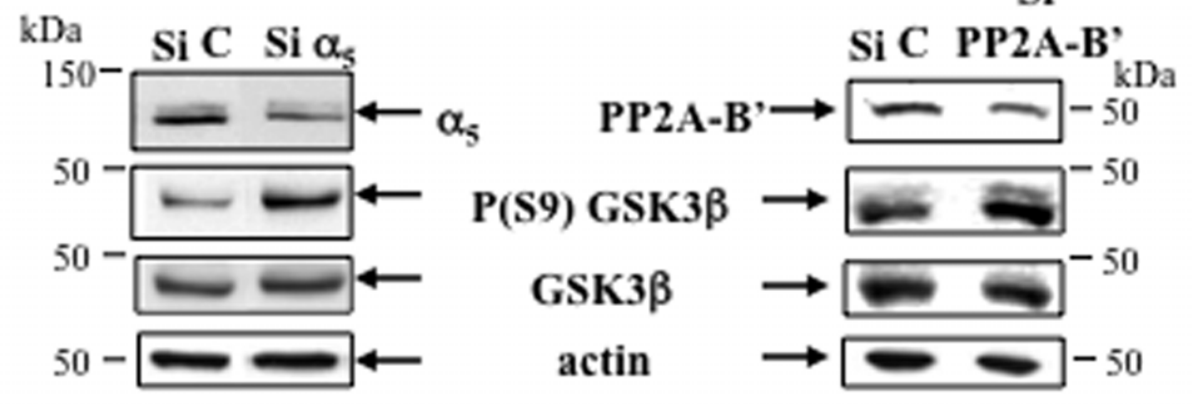

C

U937

AML patients

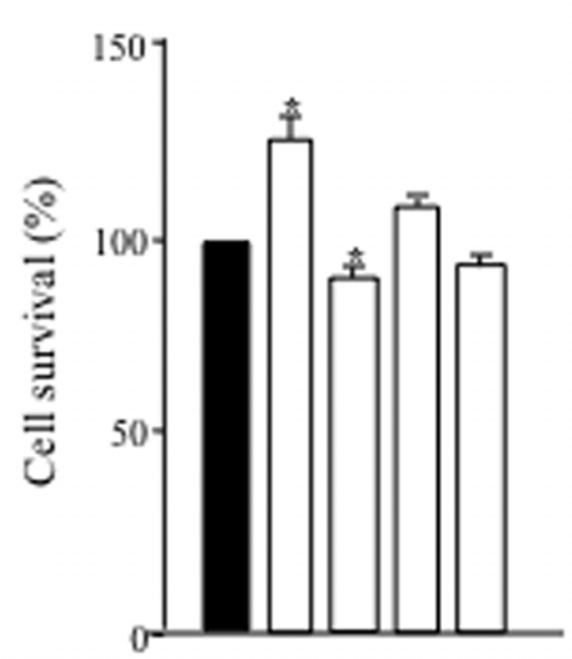

Suspension

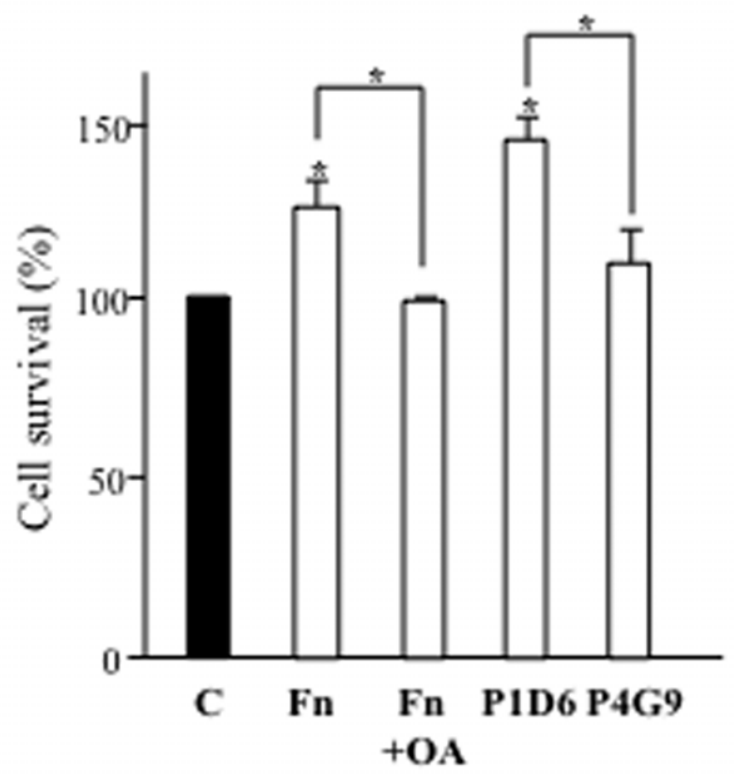

Si control: + + - -

Si $\alpha_{5}:-\quad+-\cdot$

Adhesion

Si PP2A-B': - - - +

$\mathrm{OA}:-{ }^{-}-+$ 
Figure 4. $\alpha_{5}$ integrin and PP2A both regulate GSK3 $\beta$ and survival in leukemic cells. A- Variations of inhibited forms of PP2A (P(Y307)) and GSK3 $\beta$ (P(S9)), and activated form of Akt (P(T308)), after adhesion of U937 on fibronectin \pm okadaic acid (OA, $100 \mathrm{nM})$ treatment. B- Consequences of $\alpha_{5}$ or PP2A-B' siRNA on Ser-9 phosphorylation of GSK3 $\beta$ were studied. C- Adherent U937 transfected with $\alpha_{5}$ siRNA or PP2A-B' siRNA underwent a survival assay (MTT) in serum-starved conditions as described for Fig. 1. Adhesion of cells from AML patients was performed on fibronectin or on $\alpha_{5}$ antibody (P1D6) and $\alpha_{4}$ antibody (P4G9) as described for Fig. 2 to discriminate the respective implication of both integrins in cell survival measured by APO2.7 labeling in the same conditions as for U937. OA (100 nM) was used to inhibit PP2A in U937 and AML blasts. A, B: Data are representative of three independent experiments. In C: U937 $n=3$ (mean \pm S.E.M.), AML patients $n=2$ (FAB5, mean \pm S.D.), comparison to cells in suspension: ${ }^{*} P<0.05$. doi:10.1371/journal.pone.0009807.g004

significantly change the phosphorylation status of GSK3 $\beta$ compared to suspension $(10 \% \pm 15)$. Interestingly, adhesion of U937 to coated anti- $\alpha_{5}$ antibody clone JBS5 induced a strong adhesion without cell spreading by contrast with fibronectin and clone P1D6 (not shown and [25]) but was not efficient to trigger GSK3 $\beta$ dephosphorylation (Fig. 2C). Of note, adhesion of U937 on non-specific Ig did not induce changes in phosphorylation of GSK3 $\beta$ nor in cell survival (not shown and [8]).

These data unravel a differential control of Ser-9 phosphorylation of GSK3 $\beta$ by $\alpha_{4} \beta_{1}$ and $\alpha_{5} \beta_{1}$ integrins, allowing activation of the enzyme. However, upon adhesion of serum-starved leukemic cells on fibronectin, $\alpha_{5} \beta_{1}$ alone seems to support GSK3$\beta$ activation.

\section{Involvement of PP2A in $\alpha_{5} \beta_{1}$-mediated GSK3 $\beta$ activation and cell survival}

The phosphatase PP2A is a partner of $\beta_{1}$ integrins in the control of cell survival [26] and regulates Ser-9 phosphorylation of GSK $3 \beta$ [7]. As shown in Fig. 3A, the inhibitory Ser-9 phosphorylation of GSK $3 \beta$ in the cytosolic/membrane fraction was found to be strongly decreased in adhesion compared to suspension. Moreover, the active form of GSK3 $\beta$ (Ser-9 dephosphorylated GSK $3 \beta$ ) was increased in $\alpha_{5}$ integrin immunoprecipitate from adherent U937 comparatively to suspension and was found associated with PP2A (Fig. 3B). PP2A was poorly phosphorylated on its inhibitory site (Tyr-307) in $\alpha_{5}$ immunoprecipitate from adherent U937. Interestingly, adhesion of U937 on fibronectin triggered the association of the scaffolding protein RACK1 with $\alpha_{5}$ whereas it decreased the amount of the PI 3kinase regulatory subunit p85 associated with the integrin (Fig. 3B). These data show that GSK $3 \beta$ is co-localized with $\alpha_{5}$ integrin in a molecular complex containing phosphatases and kinases potentially implicated in its regulation.

To further demonstrate that PP2A could play a role in GSK $3 \beta$ activation, we used okadaic acid (OA) to inhibit PP2A [26]. The inactive phosphorylated forms of PP2A and GSK $3 \beta$ (phosphoTyr307 PP2A and phosphoSer-9 GSK3 $\beta$, respectively) were decreased upon adhesion but restored upon treatment with OA (Fig. 4A) showing that the activation of the two enzymes were correlated. Of note, under treatment by OA, a decrease of GSK $3 \beta$ expression was constantly measured (Fig. 4A) suggesting its Ser-9 phosphorylation-dependent proteasomal degradation as demonstrated previously [27]. The PP2A regulatory subunit B' (also called B56 or PR61) is responsible for the function of PP2A in cytoskeletal stability [28] and Akt regulation [29], potentially involved in the control of cell survival and GSK $3 \beta$ regulation. Indeed we have measured a decrease of the active form of Akt (Threonine 308 phosphorylated Akt) concomitantly with the activation of PP2A and GSK3 $\beta$ in adherent leukemic cells (Fig. 4A). As shown in Fig. 4B, a decrease of $\alpha_{5} \beta_{1}$ and PP2A-B' $(40 \% \pm 5)$ expression by siRNA both triggered an increase in Ser-9 phosphorylation of GSK3 $\beta$ suggesting their roles in keeping GSK $3 \beta$ in an active state. The PP2A inhibitor OA decreased survival of adherent $\mathrm{U} 937(35 \%, \mathrm{p}<0.05)$ to the same extent as $\alpha_{5} \beta_{1}$ knockdown (Fig. 4C). SiRNA directed against the PP2A regulatory subunit $\mathrm{B}$ ' induced a moderate but significative survival decrease $(14 \%, \mathrm{p}<0.05$ statistical apparied test) in adhesion (Fig. 4G). In suspension, leukemic cells were not significantly affected under these conditions (not shown). An increase of AML cell survival was measured upon adhesion on fibronectin $(27 \% \pm 6)$ or $\alpha_{5}$ antibody (clone P1D6, 46\% \pm 3 ) but not $\alpha_{4}$ antibody (clone P4G9, 10\% \pm 7 ) compared to suspension. This improvement of AML cell survival upon adhesion was abolished by OA treatment (Fig. 4C). These results show a role for PP2A in GSK3 $\beta$ activation and cell survival of adherent leukemic cells.

Altogether, these data show that PP2A is activated in serumstarved adherent leukemic cells and cooperate with $\alpha_{5} \beta_{1}$ integrin in leukemic cell survival through the regulation of GSK3$\beta$.

\section{$\alpha_{5} \beta_{1}$ and GSK3 $\beta$ regulate TNF $\alpha$ resistance and both extrinsic and intrinsic apoptotic pathways in leukemic cells}

We have previously shown that both $\alpha_{5} \beta_{1}$ and $\alpha_{4} \beta_{1}$ integrins supported chemoresistance of U937 cells [8]. Since GSK3 $\beta$ activation is $\alpha_{5} \beta_{1}$ integrin-dependent in our conditions and has been shown to play a specific pro-survival role through the response to death receptor activation [21], we checked whether $\alpha_{5}$ and $\alpha_{4}$ integrins could be differentially involved in TNF $\alpha$ response. The incubation of U937 with TNF $\alpha$ in serum-starved suspension conditions induced a $44 \% \pm 3(\mathrm{p}<0.01)$ decrease in cell survival (Fig. 5A). Adherent U937 were more resistant to this treatment since a decrease of $24 \% \pm 4(\mathrm{p}<0.01)$ of cell survival was measured. $\alpha_{5}$ siRNA as well as GSK $3 \beta$ siRNA, but not $\alpha_{4}$ siRNA, abolished the adhesion-dependent resistance to TNF $\alpha$ (Fig. $5 \mathrm{~A})$.

The GSK $3 \beta$-dependent TNF $\alpha$ resistance and NF- $\kappa \mathrm{B}$ activation [8] in adherent leukemic cells suggest that both extrinsic and intrinsic apoptotic pathways could be regulated by $\alpha_{5} \beta_{1}$ integrin engagement. Indeed the treatment of U937 cells with siRNA directed to $\alpha_{5}$ or GSK3 $\beta$ induced a cleavage of caspase 8 and an increase of cytosolic cytochrome $\mathrm{C}$ in favor of the activation of both apoptotic pathways in adherent leukemic cells treated by $\mathrm{TNF} \alpha$. As a result of both apoptotic pathways, caspase 3 was cleaved upon this treatment (Fig. 5B). Protection against TNF $\alpha$ confered by $\alpha_{5}$-dependent adhesion and activated GSK3 $\beta$ was confirmed in AML patient (Fig. 5B).

Thus, these data demonstrate that the engagement of $\alpha_{5} \beta_{1}$ integrin and GSK $3 \beta$ activation both support resistance to extrinsic and intrinsic pro-apoptotic pathways of serum-starved adherent leukemic cells.

\section{Discussion}

In this work, we have demonstrated that adhesion to fibronectin triggers a specific survival signaling pathway in U937 leukemic cells upon serum starvation. Importantly, this survival pathway occurs in leukemic blasts from AML patients and supports their chemoresistance [8]. The survival advantage conferred by adhesion to serum-starved leukemic cells requires the activation of GSK $3 \beta$. A signaling cascade involving the $\alpha_{5} \beta_{1}$ integrin and the phosphatase PP2A is responsible for Ser-9 dephosphorylation and thus activation of GSK $3 \beta$. 


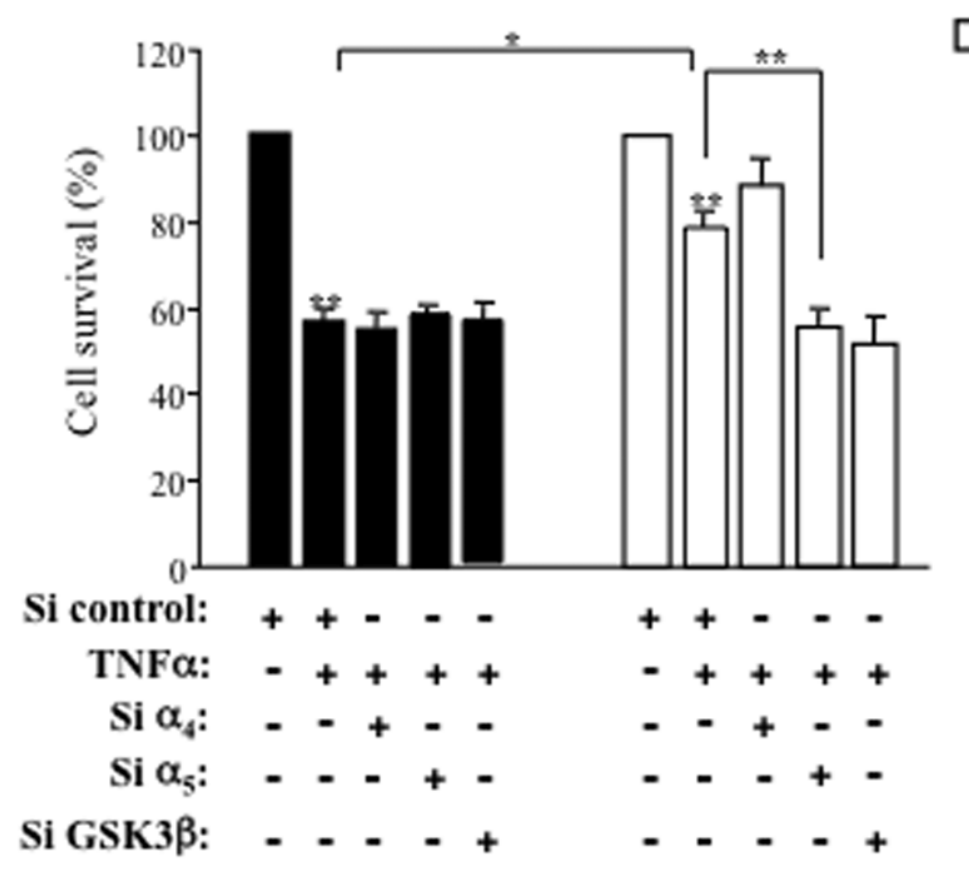

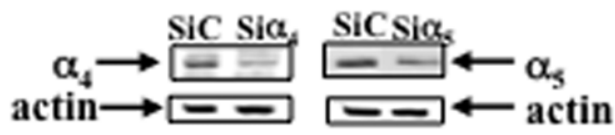

Si

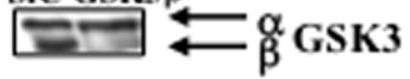

B
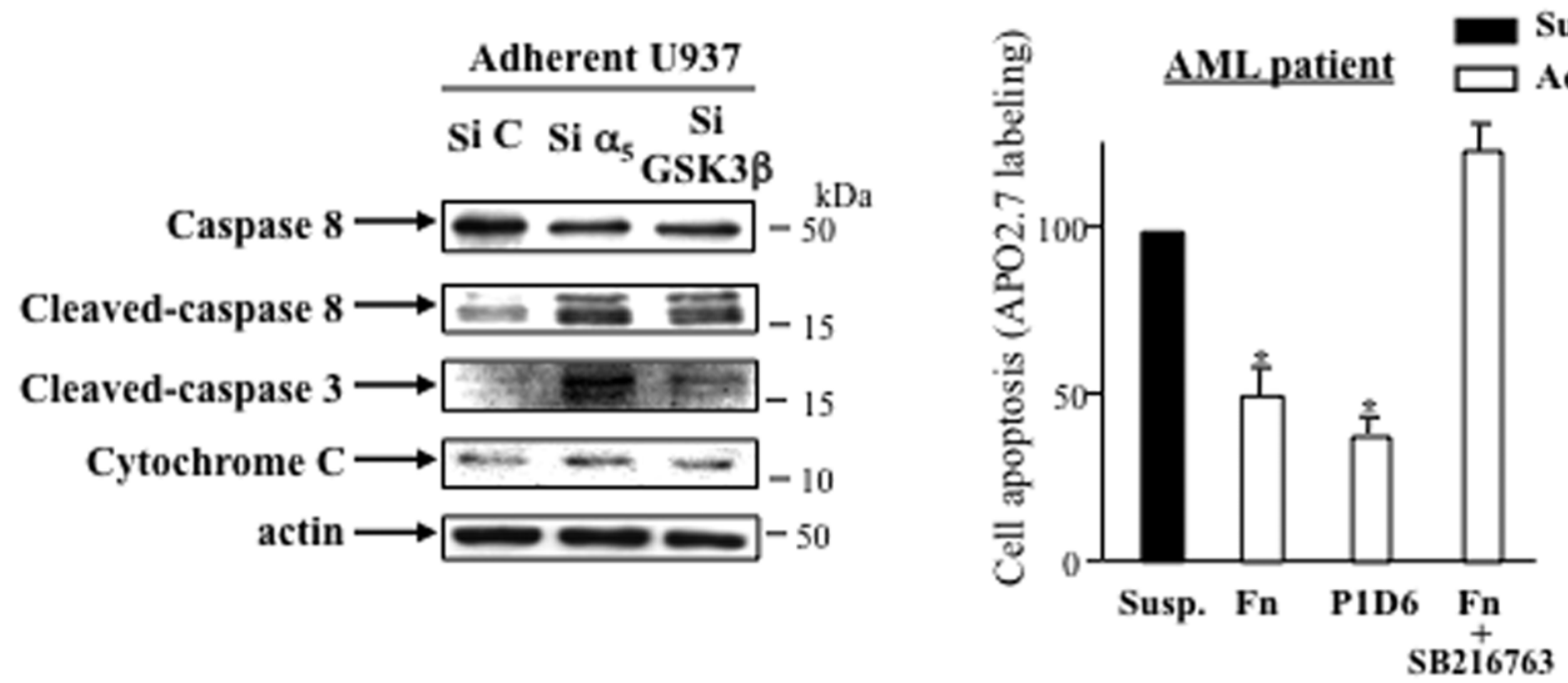

Figure 5. $\alpha_{5}$ integrin and GSK3 $\beta$ regulate the response to TNF $\alpha$ and both extrinsic and intrinsic apoptotic pathways in adherent leukemic cells. A- U937 transfected with $\alpha_{4}, \alpha_{5}$ or GSK3 $\beta$ siRNA in suspension or adhesion were treated with TNF $\alpha(10 \mathrm{ng} / \mathrm{ml})$ for 4 hours and cell survival assays (MTT) were performed as described for Fig. 1. Mean \pm S.E.M. $n=3,{ }^{*} P<0.05 * * P<0.01$. Right panel shows the efficacy of siRNA directed to GSK3 $\beta, \alpha_{4}$ and $\alpha_{5}$ integrins. B- Extrinsic (caspase-8) and intrinsic (cytochrome C) or both (caspase-3) apoptotic pathways were studied by Western blotting in TNF $\alpha$-treated adherent U937 treated with siRNA against $\alpha_{5}$ or GSK3B. SiC $=$ Sicontrol, representative of three independent experiments. On the right side is shown cell apoptosis (APO2.7 labeling) measured in TNF $\alpha$-treated blasts from AML patients in suspension or in adhesion on fibronectin or on P1D6 $\alpha_{5}$ antibody as described in the legend of Fig. 2 ( $n=2$ FAB5, mean \pm S.D., $\left.{ }^{*} P<0.05\right)$. The treatment with the GSK3 $\beta$ inhibitor SB216763 was peformed as described for Fig. 1. doi:10.1371/journal.pone.0009807.g005

In adherent conditions, co-localization of GSK3 $\beta$ and PP2A with $\alpha_{5}$ integrin in the membrane compartment correlated with Ser-9 dephosphorylation of GSK3 $\beta$ suggesting the activation of the enzyme under these conditions. Indeed, inhibition of $\alpha_{5} \beta_{1}$ and PP2A by siRNA or pharmacological drugs induced an increase of the Ser-9 phosphorylated inhibited form of GSK $3 \beta$. The $\beta_{1}$ 
integrin/PP2A pathway of GSK3 $\beta$ activation may be specific of some integrin heterodimers since it has been demonstrated downstream of $\alpha_{2} \beta_{1}$ [5], $\alpha_{5} \beta_{1}$ but not $\alpha_{4} \beta_{1}$ engagement. Moreover, in our experiments, serum starvation was required to trigger the integrin-dependent GSK3 activation (not shown). The $\alpha_{5} \beta_{1} /$ GSK $3 \beta$ pathway supports $30 \%$ of survival in adherent leukemic cells. Interestingly, we have previously implicated this survival pathway in cell adhesion-mediated drug resistance, where it was shown to allow a $30 \%$ increase in survival [8]. Our data also demonstrate that the $\alpha_{5} \beta_{1} /$ GSK $3 \beta$ pathway is involved in TNF $\alpha$ resistance, caspase 8 and cytochrome $\mathrm{C}$ regulation, and activation of the transcriptional factor NF- $\kappa \mathrm{B}$ [8]. Thus, $\alpha_{5} \beta_{1}$-mediated activation of GSK3 $\beta$ modulates both extrinsic and intrinsic apoptosis signaling pathways [15].

The $\alpha_{5} \beta_{1} /$ GSK $3 \beta$ pathway could modulate diverse signaling pathways controlling cell survival. ERK activation has been described to control cell survival that is linked to integrin engagement upon serum starvation [30] or Fas stimulation [26]. Moreover, GSK3 $\beta$ regulates MEKK1 demonstrating its implication in the stress-activated protein kinase pathway [31]. In our experiments, ERK or p38 inhibition did not influence cell survival (not shown). Interestingly, the activity of c-Jun N-terminal kinase (JNK), which is found constitutively activated in most patients with acute myeloid leukemia, has been correlated with a «multidrug» anthracycline resistance [32] and controls fibronectin survival signaling under serum-starvation conditions [33]. Our preliminary data suggest that JNK is activated in adherent U937. It remains to determine whether, in our experimental model, JNK activation is modulated by GSK $3 \beta$.

Our data show that adhesion of U937 on fibronectin triggers the association of the scaffolding protein RACK1 with $\alpha_{5} \beta_{1}$. Interestingly, RACK 1 has been described as a signal integrator between growth factor receptor and $\beta 1$ integrin [34]. PP2A and the PI 3-kinase regulatory subunit p85 are among the proteins whose recruitment and dissociation are modulated by RACK 1 . In our experiments, both an increase of activated GSK $3 \beta$ and a decrease of p85 were observed in $\alpha_{5}$ immunoprecipitate from adherent U937. This result suggests that the integrin-dependent activation of GSK $3 \beta$ could result from both increased PP2A and decreased PI 3-kinase/Akt activities [5]. Accordingly we measured a concomitant decrease of the active form of Akt with GSK3 $\beta$ activation in adherent leukemic cells. Thus, survival of U937 in starved conditions may be linked to a quiescence status with decreased proliferative and migration capacities [35]. However, the organization of the cytoskeleton seems to play a key role for the $\alpha_{5} \beta_{1}$-dependent activation of GSK $3 \beta$ since adhesion through the $\alpha_{5} \beta_{1}$ antibody clone JBS5 impaired specifically cell spreading and did not trigger GSK3 $\beta$ activation. Whether RACK1 directly regulates PP2A activity or targets GSK $3 \beta$ and PP2A catalytic/ regulatory subunits to specific locations is an open question. Interestingly, it has been shown that RACK1 is a component of the signaling pathway of the p55 TNF receptor [36] and is implicated in the resistance to apoptotic stimuli in hematopoietic cells [37]. Thus, RACK1 could regulate the death-antagonizing complex involving GSK3 $\beta$ at TNF receptor [21].

We have previously shown [8] that engagement of both $\alpha_{5} \beta_{1}$ and $\alpha_{4} \beta_{1}$ supported cell-adhesion mediated drug resistance of U937. However, $\alpha_{5} \beta_{1}$ alone was shown to activate GSK3 $\beta$ and TNF $\alpha$ resistance. Our unpublished data demonstrate that $\alpha_{4} \beta_{1}$ integrin controls U937 survival in adhesion through the tyrosine kinase Pyk2 activation. It suggests that $\alpha_{5} \beta_{1} /$ GSK $3 \beta$ and $\alpha_{4} \beta_{1} /$ Pyk2-dependent pro-survival pathways could cooperate through the activation of specific pathways of resistance to extrinsic and intrinsic pro-apoptotic pathways. Interestingly, our preliminary data show that the $\alpha_{4} \beta_{1} /$ Pyk2 cell survival pathway in adherent U937 involves PI 3-kinase activation and Bcl-xL expression. Since we have shown that the GSK3 $\beta$-dependent survival pathway occurred in U937 but not in HL-60 and KG1 cell lines, it could be interesting to compare their $\alpha_{5}$ or $\alpha_{4}$-dependent adhesive capacities. Notably, and by contrast with U937, RACK1 increase and PI 3-kinase subunit p85 decrease were not observed in $\alpha_{5}$ immunoprecipitates from adherent HL-60 (not shown). However, we demonstrate that AML cells from patients classified along different FAB trigger mostly the GSK3 $\beta$-dependent survival pathway upon adhesion onto fibronectin. Except a myelomonocytic phenotype, this survival pathway was not correlated with other clinico-biological parameters in patients.

In conclusion, we propose GSK3 $\beta$ activation as a new adhesion-dependent cell survival pathway that is regulated by the engagement of specific integrin heterodimers. It could control a pro-survival response to death receptors but also intrinsic prosurvival pathways under stress conditions. Importantly, the prosurvival GSK3 $\beta$-dependent pathway may represent a new therapeutic target in cancer cells whose resistance to therapy is supported by cell adhesion.

\section{Acknowledgments}

The authors acknowledge the «plateforme de cytométrie» in IFR150 and Drs Michèle Allouche and Kelly Thornber for critical reading of the manuscript.

\section{Author Contributions}

Conceived and designed the experiments: FDTC MD EB LY BP CRS. Performed the experiments: FDTC MD JB CRS. Analyzed the data: FDTC JB EB LY CRS. Wrote the paper: FDTG BP CRS.

\section{References}

1. Jope RS, Johnson GV (2004) The glamour and gloom of glycogen synthase kinase-3. Trends Biochem Sci 29: 95-102.

2. Dajani R, Fraser E, Roe SM, Young N, Good V, et al. (2001) Crystal structure of glycogen synthase kinase 3 beta: structural basis for phosphate-primed substrate specificity and autoinhibition. Cell 105: 721-732.

3. Novak A, Hsu SC, Leung-Hagesteijn C, Radeva G, Papkoff J, et al. (1998) Cell adhesion and the integrin-linked kinase regulate the LEF-1 and beta-catenin signaling pathways. Proc Natl Acad Sci U S A 95: 4374-4379.

4. Etienne-Manneville S, Hall A (2003) Cdc42 regulates GSK-3beta and adenomatous polyposis coli to control cell polarity. Nature 421: 753-756.

5. Ivaska J, Nissinen L, Immonen N, Eriksson JE, Kähäri VM, et al. (2002) Integrin alpha 2 beta 1 promotes activation of protein phosphatase $2 \mathrm{~A}$ and dephosphorylation of Akt and glycogen synthase kinase 3 beta. Mol Cell Biol 22: $1352-1359$.

6. Sutherland C, Leighton IA, Cohen P (1993) Inactivation of glycogen synthase kinase-3 beta by phosphorylation: new kinase connections in insulin and growthfactor signalling. Biochem J 296: 15-19.
7. Lee YI, Seo M, Kim Y, Kim SY, Kang UG, et al. (2005) Membrane depolarization induces the undulating phosphorylation/dephosphorylation of glycogen synthase kinase 3beta, and this dephosphorylation involves protein phosphatases 2A and 2B in SH-SY5Y human neuroblastoma cells. J Biol Chem 280: 22044-22052.

8. De Toni F, Racaud-Sultan C, Chicanne G, Mas VM, Cariven C, et al. (2006) A crosstalk between the Wnt and the adhesion-dependent signaling pathways governs the chemosensitivity of acute myeloid leukemia. Oncogene 25: 3113-3122.

9. Ishikawa F, Yoshida S, Saito Y, Hijikata A, Kitamura H, et al. (2007) Chemotherapy-resistant human AML stem cells home to and engraft within the bone-marrow endosteal region. Nat Biotechnol 25: 1315-1321.

10. Ayala F, Dewar R, Kieran M, Kalluri R (2009) Contribution of bone microenvironment to leukemogenesis and leukemia progression. Leukemia 23: 2233-2241.

11. Ougolkov AV, Bone ND, Fernandez-Zapico ME, Kay NE, Billadeau DD (2007) Inhibition of glycogen synthase kinase-3 activity leads to epigenetic silencing of 
nuclear factor kappaB target genes and induction of apoptosis in chronic lymphocytic leukemia B cells. Blood 110: 735-742.

12. Steinbrecher KA, Wilson W, 3rd, Cogswell PC, Baldwin AS (2005) Glycogen synthase kinase 3beta functions to specify gene-specific, NF-kappaB-dependent transcription. Mol Cell Biol 25: 8444-8455.

13. Hoeflich KP, Luo J, Rubie EA, Tsao MS, Jin O, et al. (2000) Requirement for glycogen synthase kinase-3beta in cell survival and NF-kappaB activation. Nature 406: 86-90.

14. Deng J, Xia W, Miller SA, Wen Y, Wang HY, et al. (2004) Crossregulation of NF-kappaB by the APC/GSK-3beta/beta-catenin pathway. Mol Carcinog 39: $139-146$.

15. Beurel E, Jope RS (2006) The paradoxical pro- and anti-apoptotic actions of GSK3 in the intrinsic and extrinsic apoptosis signaling pathways. Prog Neurobiol 79: 173-189.

16. Liao X, Zhang L, Thrasher JB, Du J, Li B (2003) Glycogen synthase kinase3beta suppression eliminates tumor necrosis factor-related apoptosis-inducing ligand resistance in prostate cancer. Mol Cancer Ther 2: 1215-1222.

17. Ghosh JC, Altieri DC (2005) Activation of p53-dependent apoptosis by acute ablation of glycogen synthase kinase-3beta in colorectal cancer cells. Clin Cancer Res 11: 4580-4588.

18. Ougolkov AV, Fernandez-Zapico ME, Savoy DN, Urrutia RA, Billadeau DD (2005) Glycogen synthase kinase-3beta participates in nuclear factor kappaBmediated gene transcription and cell survival in pancreatic cancer cells. Cancer Res 65: 2076-2081.

19. Shakoori A, Ougolkov A, Yu ZW, Zhang B, Modarressi MH, et al. (2005) Deregulated GSK3beta activity in colorectal cancer: its association with tumor cell survival and proliferation. Biochem Biophys Res Commun 334: 1365-1373.

20. Ougolkov AV, Billadeau DD (2006) Targeting GSK-3: a promising approach for cancer therapy? Future Oncol 2: 91-100.

21. Sun M, Song L, Li Y, Zhou T, Jope RS (2008) Identification of an antiapoptotic protein complex at death receptors. Cell Death Differ 15: 1887-1900.

22. Kotliarova S, Pastorino S, Kovell LC, Kotliarov Y, Song H, et al. (2008) Glycogen synthase kinase-3 inhibition induces glioma cell death through cMYC, nuclear factor-kappaB, and glucose regulation. Cancer Res 68: 6643-6651.

23. Hazlehurst LA, Landowski TH, Dalton WS (2003) Role of the tumor microenvironment in mediating de novo resistance to drugs and physiological mediators of cell death. Oncogene 22: 7396-7402.

24. Kapur R, Cooper R, Zhang L, Williams DA (2001) Cross-talk between alpha(4)beta(1)/alpha(5)beta(1) and c-Kit results in opposing effect on growth and survival of hematopoietic cells via the activation of focal adhesion kinase, mitogen-activated protein kinase, and Akt signaling pathways. Blood 97: 1975-1981.

25. Bao W, Strömblad S (2002) Use of an Immobilized Monoclonal Antibody to Examine Integrin alpha5betal Signaling Independent of Cell Spreading. Biol Proced Online 4: 81-87.
26. Chetoui N, Gendron S, Chamoux E, Aoudjit F (2006) Collagen type I-mediated activation of ERK/MAP Kinase is dependent on Ras, Raf-1 and protein phosphatase 2A in Jurkat T cells. Mol Immunol 43: 1687-1693.

27. Failor KL, Desyatnikov Y, Finger LA, Firestone GL (2007) Glucocorticoidinduced degradation of glycogen synthase kinase-3 protein is triggered by serumand glucocorticoid-induced protein kinase and Akt signaling and controls betacatenin dynamics and tight junction formation in mammary epithelial tumor cells. Mol Endocrinol 21: 2403-2415.

28. Viquez NM, Li CR, Wairkar YP, DiAntonio A (2006) The B' protein phosphatase $2 \mathrm{~A}$ regulatory subunit well-rounded regulates synaptic growth and cytoskeletal stability at the Drosophila neuromuscular junction. J Neurosci 26: 9293-9303.

29. Van Kanegan MJ, Adams DG, Wadzinski BE, Strack S (2005) Distinct protein phosphatase 2A heterotrimers modulate growth factor signaling to extracellular signal-regulated kinases and Akt. J Biol Chem 280: 36029-36036.

30. Gu J, Fujibayashi A, Yamada KM, Sekiguchi K (2002) Laminin-10/11 and fibronectin differentially prevent apoptosis induced by serum removal via phosphatidylinositol 3-kinase/Akt- and MEK1/ERK-dependent pathways. J Biol Chem 277: 19922-19928.

31. Kim JW, Lee JE, Kim MJ, Cho EG, Cho SG, et al. (2003) Glycogen synthase kinase 3 beta is a natural activator of mitogen-activated protein kinase/ extracellular signal-regulated kinase kinase kinase 1 (MEKK1). J Biol Chem 278: 13995-14001.

32. Cripe LD, Gelfanov VM, Smith EA, Spigel DR, Phillips CA, et al. (2002) Role for c-jun N-terminal kinase in treatment-refractory acute myeloid leukemia (AML): signaling to multidrug-efflux and hyperproliferation. Leukemia 16: 799-812.

33. Almeida EA, Ilic D, Han $\mathrm{O}$ Hauck CR, Jin F, et al. (2000) Matrix survival signaling: from fibronectin via focal adhesion kinase to c-Jun $\mathrm{NH}(2)$-terminal kinase. J Cell Biol 149: 741-754.

34. Kiely PA, Leahy M, O'Gorman D, O'Connor R (2005) RACK1-mediated integration of adhesion and insulin-like growth factor I (IGF-I) signaling and cell migration are defective in cells expressing an IGF-I receptor mutated at tyrosines 1250 and 1251. J Biol Chem 280: 7624-7633.

35. Hermanto U, Zong CS, Li W, Wang LH (2002) RACK1, an insulin-like growth factor I (IGF-I) receptor-interacting protein, modulates IGF-I-dependent integrin signaling and promotes cell spreading and contact with extracellular matrix. Mol Cell Biol 22: 2345-2365.

36. Tcherkasowa AE, Adam-Klages S, Ktuse ML, Wiegmann K, Mathieu S, et al. (2002) Interaction with factor associated with neutral sphingomyelinase activation, a WD motif-containing protein, identifies receptor for activated Ckinase 1 as a novel component of the signaling pathways of the p55 TNF receptor. J of Immunol 169: 5161-5170.

37. Mourtada-Maarabouni M, Kirkham L, Farzaneh F, Williams GT (2005) Functional expression cloning reveals a central role for the receptor for activated protein kinase C 1 (RACK1) in T cell apoptosis. J Leukoc Biol 78: 503-514. 